\title{
Estranging German Lieder: Kurt Schwaen's Settings of Günter Kunert
}

\section{HEIDI HART}

The former East German composer Kurt Schwaen’s 1996 piano work “Nocturne lugubre” plays on a painfully slow four-note ostinato over the course of ten to twelve minutes. At the same time, this extensive, even obsessive piece spools out extended high-treble runs and chord clusters against the E-Gsharp-G-natural-A ostinato, stretched across the bass and tenor keyboard range, ${ }^{1}$ with a breathtakingly open-ended quality. The piece evokes as much nostalgia (perhaps a form of "Ostaglie") for Soviet-era cosmic fantasy as it does the disorienting political environment in post-reunification Germany. Meanwhile, the four-note pattern's broken-record quality draws attention to itself as sonic artifice and artifact. As Fredric Jameson has noted, Verfremdung or estrangement in Bertolt Brecht's sense can work homeopathically, reifying aesthetic material to expose its very cultural reification; such hardening of musical elements exposes their own status as objects, ${ }^{2}$ so that they demand close listening that is as engaged as it is critical. Throughout Kurt Schwaen's oeuvre, including his vocal music, this estrangement works in a paradox of kinetic pleasure and discomfort. What his fellow Brecht collaborator Hanns Eisler called the "schöne Klang"3 or "beautiful sound" of nineteenth-century harmony, so easily appropriated for capitalist or fascist ends a hundred years later, becomes a tool of its own critique.

Though Kurt Schwaen was well known in the GDR as a Brecht collaborator and writer of children's school songs, and though he lived until 2007, continuing to mentor younger musicians in Berlin, his work has not received the post-Cold War attention given to his fellow Brechtians Hanns Eisler and Paul Dessau. Several recent studies of classical-music heritage in the GDR, Elaine Kelly's 2014 Composing the Canon in the German Democratic Republic and Frackman and Powell's 2015 edited volume Classical Music in the German Democratic Republic, do not mention him at all. Schwaen's music, sometimes baldly didactic and more often probingly idiosyncratic, is difficult to place in a clear category. His importance to East German culture cannot be denied, however, and his music retains enough power to keep some of today's young pianists returning to his "Nocturne lugubre" like an obsession. This article provides background on Schwaen's life and work, context on his settings of poetry by Günter Kunert, and analysis of their collaborative song cycle Liebsame Beschäftigung, as a re-functioning of the Lieder genre with subtly estranging gestures. Unlike most socialist-realist adaptations in a similar vein, Schwaen's song cycle does not rely on formal parody or explicit quotation ${ }^{4}$ but rather unsettles metric and musical-syllabic conventions in order to expose the act of Lieder singing as unnatural in the face of violence and injustice - the troubling subjects of the cycle's texts.

\footnotetext{
${ }^{1}$ Kurt Schwaen, "Nocturne lugubre" (Berlin: Verlag Neue Musik, 1996).

${ }^{2}$ Fredric Jameson, Brecht and Method (London: Verso, 1998), 169.

${ }^{3}$ See Ernst Bloch and Hanns Eisler, "Die Kunst zu Erben," in Die Expressionismusdebatte: Materialien zu einer marxistischen Realismuskonzeption, ed. Hans-Jürgen Schmitt (Frankfurt: Suhrkamp, 1973), 260. This text addresses the formalism debates of the late 1930s, in which Georg Lukács and Bloch differed most vehemently on the question of Expressionism and its potential links to fascism.

${ }^{4}$ Elaine Kelly, Composing the Canon in the German Democratic Republic: Narratives of Nineteenth-century Music (Oxford: Oxford University Press, 2014), 140, https://doi.org/10.1093/acprof:oso/9780199998098.001.0001.
} 
Raised in a Silesian mining town near the Polish border, Kurt Schwaen witnessed the First World War, the Weimar Republic, the rise of National Socialism, the Second World War, the Cold War in the GDR, and finally the fall of the Berlin Wall and German reunification before his death in 2007. He was arrested for Communist activity in Berlin and held in a Gestapo prison for three years (1935-38) during the Nazi era; after his release, he found his way back to everyday human activity by working as a pianist in experimental dance studios that drew on Expressionist impulses (Ausdruckstanz) along the lines of Martha Graham's work in the U.S. Though this intensely charged style appears to contradict the distancing, objectivist aesthetic that appealed to many Communist artists like Schwaen, and though one of his collaborators, Mary Wigman, was notoriously complicit in Nazi ideology, the composer wanted to be working again. He did find kindred political spirits in choreographers and dancers like Oda Schottmüller, who worked actively in a resistance group and was beheaded by the Nazis in 1943. Schwaen also found elements of 1930s Ausdruckstanz that helped to form his own playful take on aesthetic distancing; the use of masks expressed the strangeness of Persephone's Underworld life in a piece by Schottmüller, for example, and embodied the extra-human or grotesque in a form at once plastic and fixed. ${ }^{5}$ Most of all, Schwaen appreciated choreographers' idiosyncratic responses to music by Beethoven, Reger, and Brahms, giving it arbitrary titles and cuts:

Ich mußte lernen, daß die Tänzer beliebige Titel unbedenklich mit bisweilen dazu ganz ungeeigneter Musik verbanden, ja, daß sie Kompositionen auch ziemlich willkürlich zusammenstrichen, wie sie es für ihren Tanz gerade für erforderlich hielten. ${ }^{6}$

I had to learn that the dancers didn't hesitate to link random titles to music that to that point would have been a completely inappropriate fit, yes, that the compositions were also cut rather impulsively, as the dance required.

A decade before Hanns Eisler and Theodor Adorno's 1947 Music for the Films appeared during their U.S. exile, Schwaen was paying close attention to unlikely musical pairings; he discovered that, like counterpoint in film, music did not have to align with extra-musical material, and that an "inappropriate" fit could give the work critical rigor.

Improvisation and the asymmetrical meters of Eastern European dance music also figured in Schwaen's early development, as he started to bring his own music into the dance studio. He found that "Musik war Stimulator, nicht Mitgestalter"7 ("music was a stimulator, not a co-creator"); this kinetic sense of music's force informs his later vocal music as well. Though he undertook traditional composition training under Fritz Lubrich, who had studied with Max Reger, Schwaen worked throughout his career to integrate the rhythmic intensity of modernist dance with European musical conventions. After the war, he met Bertolt Brecht and began collaborating with the poet and playwright, whose Verfremdungseffekt aligned well with the musical contradictions Schwaen had explored as a dance-studio pianist. In 1955 the playwright asked him to collaborate on his earlier children's Lehrstück (teaching piece) Die Horatier und die Kuriatier, introducing him to conventions of "epic theater" and the critical potential of the musical gestus. In the Brechtian model, music working against text (a catchy tune set to disturbing lyrics, for example) was one way to keep audiences from getting caught up in the drama onstage and to notice the "unnaturalness"

\footnotetext{
${ }^{5}$ Geertje Andresen, Oda Schottmüller 1905-1943: Die Tänzerin, Bildhauerin und Nazigegnerin (Berlin: Lukas Verlag, 2005), 215-16.

${ }^{6}$ Kurt Schwaen, quoted in ibid., 206. Translations are the author's unless otherwise noted.

${ }^{7}$ Kurt Schwaen, Stufen und Intervalle: Ein Komponist zwischen Gesellschafts- und Notensystemen (Essen: Die Blaue Eule, 1996), 32.
} 
of the act of singing. Brecht's intention, however difficult to bring about in live performance, was to expose historical realities and present injustices by leaving gaps in theatrical illusion. Musical contradictions, or placards stating the action before it occurs onstage, work like masks in ancient and medieval plays (or in Oda Schottmüller's modernist dance) to block the empathic or cathartic impulse and to incite critical thought. Audiences are meant to step back and find the places where word and action do not line up. As Brecht expressed it in his pedagogical Kleines Organon für das Theater in 1948-49,

Oder man denke an einen Mann, der in einem Tal eine Rede hält, in der er mitunter seine Meinung ändert lediglich Sätze spricht, die sich widersprechen, so daß das Echo, mitsprechend, die Konfrontation der Sätze vornimmt. ${ }^{8}$

Or one thinks of a man talking in a valley, where he changes his mind along the way or simply speaks sentences that contradict themselves, so that the accompanying echo performs the sentences' confrontation.

Describing Brecht's work with composers at the piano in his studio, Schwaen noted that the playwright wanted each song's bones to stick out, "das nackte Gerüst einer Komposition unverhüllt hervortreten zu lassen" ("to let the naked scaffolding of a composition come forward"). To "bare the device," as the Russian formalists would have it, kept music from casting an illusory spell.

Along with his fellow Brecht collaborators Paul Dessau and Hanns Eisler, Schwaen developed a musical language at once direct and challenging, though he did not share in Eisler's fraught relationship to Schoenberg's twelve-tone model. Throughout his career in the German Democratic Republic, lasting well after Brecht's death in 1956, Schwaen contributed actively to the East Berlin school system, composing didactic children's songs (many former East Germans can still hum "Wenn Mutti früh zur Arbeit geht," on helping with family chores while both parents work) and serving as musical advisor to the Volksbühne Theater. His solo vocal music, faithful to the Lieder genre at least in its intimate scoring with piano, is far more complex than the aphoristic songs for which he is best known. Though the danger of "formalism" continued to haunt East German composers after Hanns Eisler's controversial projects in the early 1950s, "[o]ne formal possibility peculiar to the GDR was a particular reappropriation of [classical] 'heritage' in the form of a partly modernist rewriting." ${ }^{10}$ Paul Dessau's work is notable for this; Schwaen's has been less appreciated until recently. Its subject matter may surprise as well. The GDR was founded as the antifascist state after the Second World War, and for all its later Soviet-style demagoguery, glimmers of postwar idealism remained in Kurt Schwaen's songs for nonviolence, equality, and meaningful collective work.

Composing mid-twentieth-century Lieder in the ostensibly lyric mode, the committed Socialist Schwaen took on more than a century of bourgeois tradition. Though Schubert's bleak late songs and Schumann's biting, obsessive irony had critiqued the Biedermeier comfort zone, and though, as Charles Rosen has pointed out, nineteenth-century Lieder functioned as a sly reclaiming of the epic mode, with its monumental landscapes and human furors, ${ }^{11}$ the Liederabend managed to domesticate the Erl-king, Gretchen, Mignon, and the Dichterliebe's bitter poet. In Schubert's day, the newly accessible pianoforte

\footnotetext{
${ }^{8}$ Bertolt Brecht, "Kleines Organon für das Theater," in Bertolt Brecht, Große kommentierte Berliner und Frankfurter Ausgabe, eds. Werner Hecht, Jan Knopf, Werner Mittenzwei, and Klaus-Detlef Müller, Vol. 23, Schriften 3 (Frankfurt: Suhrkamp, 1993), 71.

${ }^{9}$ Schwaen, Stufen und Intervalle, 58.

${ }^{10}$ Kyle Frackman and Larson Powell, eds., Classical Music in the German Democratic Republic: Production and Reception

(Rochester, NY: Camden House, 2015), 8.

${ }^{11}$ See Charles Rosen, The Romantic Generation (Cambridge, MA: Harvard University Press, 1995), 125.
} 
"offered the Viennese middle class what aristocrats had heard in their private salons during the previous generation," 12 an example, from the Marxist perspective, of technological material pressing social-aesthetic change. ${ }^{13}$ As the educated middle class began to host song concerts in their private living rooms, social convention began to ossify around music as potentially explosive as it was intimate. Like Schwaen in his penchant for estranging the Lieder genre, Hanns Eisler complained in the early 1960s about the continuing practice, even after Hitler's notorious musical appropriations, of Lieder performance as sentimental, socially conventional entertainment. ${ }^{14}$ In our own time, the "classic" and still much-used pedagogical guide to the song recital admonishes singers that "[i]n the case of a recital, a short time assigned for social meeting is beneficial for all concerned. The party fulfills this need ... [as] part of the artist's duty" if he or she is to remain on the musical market. ${ }^{15}$ The use of music for either fascist or capitalist ends was anathema to Socialist composers in the GDR, however uncomfortable they may have been with Party restrictions on art (Eisler's prohibited Faust-opera project is well known; his slim but damning Stasi file reveals his agonistic place in East Berlin before his death in $1962^{16}$ ). Similarly to Brecht in the playwright's efforts to engage audiences in critique rather than in the "cult of beauty," ${ }^{17}$ Kurt Schwaen praised other composers like Wilhelm Weisman for writing declamatory songs that emphasized "die Konfrontation des Sängers mit seinem Publikum"18 ("the confrontation of the singer with his public") rather than that artist's "duty" to chat over refreshments with the audience. Singing Schwaen's Lieder demands a paradox of dry precision and kinetic momentum, challenging the audience to listen closely to the text and ask just what it means to sing about war, death, and poverty.

In Schwaen's song cycle Liebsame Beschäftigung, estrangement works most often the syllabicmelodic level. The composer destabilizes speech rhythms to accentuate weaker syllables instead of the usual stressed beats, highlighting the strangeness and difficulty of singing about burning gasoline and plaster soaked with blood. Even the cycle's title, which could be translated with some ironic distance as "Endearing Employment" or "Pleasant Pursuit," draws attention to the word "liebsam," hardly ever used today in German; the word "unliebsam," or "unpleasant" is more common but still carries quaint associations. ${ }^{19}$ An English example that approximates the semantic discomfort of "liebsam" might be "seemly" as detached from the more commonplace "unseemly" and also carrying a whiff of preciousness. Schwaen's cycle traces dystopian city walks and uneasy indoor moments, hardly pleasant experiences to document in song. At the stress-accentual level, such unease occurs more kinetically than cognitively, a phenomenon my examples will explore, after a brief introduction to the texts by still-living poet Günter Kunert.

Born in 1929 and ostracized during the Nazi period for having a Jewish mother, Kunert is known for his politically engaged fiction and poetry heavily influenced by Brecht and iconic East German poet Johannes Becher. His distrust of easy faith in human progress has earned him the nickname "Teiresias der

\footnotetext{
${ }^{12}$ Alice M. Hanson, "Vienna, City of Music," in Schubert's Vienna, ed. Raymond Erickson (New Haven and London: Yale University Press, 1997), 107, https://doi.org/10.2307/i.ctt1ww3v2b.11.

13 "Das Hammerklavier ermöglichte eine andere Art von Musik als das Cembalo, die Wagnerische Instrumentation ist ohne das Ventilhorn undenkbar" ("The pianoforte made possible music different from that made on the harpsichord, Wagnerian instrumentation is unthinkable without the valve horn"), in Bloch and Eisler, "Die Kunst zu Erben," 260.

${ }^{14}$ Hans Bunge, Fragen Sie mehr über Brecht: Hanns Eisler im Gespräch (Munich: Rogner and Bernhard, 1976), 150.

${ }^{15}$ Shirlee Emmons and Stanley Sonntag, The Art of the Song Recital (New York: Schirmer Books, 1979), 167.

${ }^{16}$ Archiv der Behörde des Bundesbeauftragten für die Unterlagen des Staatssicherheitsdienstes der ehemaligen Deutschen Demokratischen Republik (BStU), Sign. 14247.

${ }^{17}$ See Brecht, "Kleines Organon für das Theater," 65-66.

${ }^{18}$ Schwaen, Stufen und Intervalle, 211.

${ }^{19}$ Thanks to Brecht-and-music scholar Andreas Aurin for pointing out this distinction.
} 
deutschen Lyrik""20 ("Tiresias of German poetry"). He is also known for his decision to leave East Germany in 1979, after publicly supporting dissident singer-songwriter Wolf Biermann in 1976, and for his historical pessimism amid a heated "lyric debate" in West Germany in the early 1980s. Though it may seem strange that Schwaen continued to work with a poet well known for his criticism of the GDR, such contradictions were not uncommon; despite his own support of Biermann in the early 1960s, the humiliating shutdown of his Johannes Faustus project, and the Stasi surveillance he endured, Hanns Eisler also chose to stay in the East and was a vocal supporter of the Berlin Wall. At the same time, as part of a generation younger than Brecht and Eisler (Kunert was only four years old when Hitler came to power ${ }^{21}$ ), the poet was not shaped as deeply by the 1920s German workers' movement as his older collaborators and mentors had been. During the Cold War, he felt as free to critique Socialism as he did to engage with broader questions of homeland, violence, and existential discomfort.

Kunert's poetry shows wide-ranging influences, from Brecht and his influences (most notably the medieval balladeer François Villon) to Walt Whitman and Zbigniew Herbert. ${ }^{22}$ His 1970 poem "Marx" moves in Biblical cadences, linking Marx's beard to a great flag; its anaphora (a repeated first phrase), internal echoes, and biting binaries keep it from sounding like propaganda:

Es weht wild

die Fahne dieses bedeutenden Bartes

über die immer wieder aufplatzenden Schalen

der Erde.

Es weht über wandernden Fronten.

Über dem unaufhörlichen Widerspruch und über

dem aufhörlichen.

Über den Kriegen, die von Donnerstagabend bis

Freitagfrüh scheinen:

Der ewige Friede zwischen Efeu und Eiche, zwischen Unternehmern und Unternommenen, Anordnern und Angeordneten, Machthabern und Nichtshabern, Gläubigen und denen, welche daran glauben sollen müssen.

Zwischen Welle und Ufer

währt Feindschaft: die beste, die möglich ist. ${ }^{23}$

It waves wildly

the banner of this weighty beard

over the ever-bursting rinds

of the earth.

It waves over wandering fronts.

Over endless contradiction and over

endlessness itself.

Over the wars that appear from Thursday evening

\footnotetext{
${ }^{20}$ Manfred Durzak and Hartmut Steinecke, eds., Günter Kunert: Beiträge zu seinem

Werk (Munich and Vienna: Carl Hanser, 1992), 7. Translations are mine unless otherwise indicated.

${ }^{21}$ See Jay Julian Rosellini, "Kunerts langer Abschied von Brecht - Biermanns Annäherung an Kunert,” in ibid., 276.

${ }^{22}$ See Günter Kunert, Mein Lesebuch (Frankfurt: Fischer Taschenbuch Verlag, 1983).

${ }^{23}$ Günter Kunert, "Marx," cited in Italo Michele Battafarano, "Kunerts dialektischer und Frieds skeptischer 'Marx'," in Günter Kunert: Beiträge zu seinem Werk, 69-70.
} 
to early Friday:

The eternal peace between ivy and oak, between those who take on and those taken in, those who sign off and those who resign themselves, those with power and those without, those who believe and those who are supposed to believe.

Between wave and shore

enmity stands guard: the best we can hope for.

The poem's contrast between high-flown and workaday diction shows Kunert's awareness of the aesthetic dialectics (not as much an oxymoron as this sounds) also favored by Brecht, Eisler, and Dessau; the contradiction of opposites in their textual and/or musical material often works as the engine of estrangement. At the same time, Kunert draws on ancient poetic forms such as anaphora and on Whitman's long-breathing utterances, truncating them in his own take on Brechtian interruption. Such contrasts make his work well suited for Kurt Schwaen's music, with its unsettling meters and unexpected breaks amid surprisingly singable melodies.

Kunert's early poems set by Schwaen in Liebsame Beschäftigung evoke the costs of war in city life, in love relationships, and among children. Several texts include lines that echo Communist or activist-pacifist ideology; one about a doomed mountaineering expedition includes the classic line "Stark ist jede Kette wie ihr schwächstes Glied"24 ("A chain is no stronger than its weakest link"), attributed to Lenin in a reference to the downfall of capitalism, and a lullaby that ends with the words "ein Spaten auf Erden hienieden ist mehr als ein scharfes Schwert" 25 ("a spade down here in the earth is better than a sharp sword"). For all its disturbing images of blood and bullet-riddled bodies, the cycle of poems also includes tender and even playful lines. "Das Gedicht vom Mond" compares the moon to a piece of metal painted by a child "in schlechten Farben" ("in bad colors") and yet full of tenderness ("doch voll Zärtlichkeit"). ${ }^{26}$ Schwaen's setting imitates a children's song - and at the same time complicates it with the irregular meters of Eastern European dance music. The love poem "Begegnung in der Frühe” ("Early encounter"), set by Schwaen in vocally exposed, haunting dissonance, combines comforting anaphora ("Als ich dich sah") at the beginning of each verse, only to hint at separation and even death to come ("den Häusern, die lagen wie tot"... "Als ich dich sah, wusste ich genau,/ was mit uns noch würde geschehn" ["the houses that lay as if dead ... When I saw you, I knew exactly/ what would happen with us”]). ${ }^{27}$ Here Schwaen leaves some measures silent, marked by rests, as he draws out the "melancholisches Kalkül"28 ("melancholy calculation") an unnamed critic once noted in Günter Kunert's work.

Schwaen began work with Kunert in 1956, several months after the death of Brecht, with whom Schwaen had planned several projects after Die Horatier und die Kuratier. Kunert sent the composer a proposal for a "non-classical ballet," with a note about how to recognize him when they met: "IIch habe einen Schnurrbart," to which Schwaen responded, "Und ich keinen",29 ("I have a mustache," "I have none”), and so it began. Poet and composer enjoyed a friendship with sometimes bitingly playful aspects

\footnotetext{
${ }^{24}$ Kurt Schwaen, Liebsame Beschäftigung: 11 Lieder nach Gedichten von Günter Kunert für Gesang und Klavier (Berlin: Verlag Neue Musik, 1994), 9.

${ }^{25}$ Ibid., 16.

${ }^{26}$ Ibid., 4-6.

${ }^{27}$ Ibid., 7.

${ }^{28}$ Schwaen, Stufen und Intervalle, 124.

${ }^{29}$ Ibid., 123.
} 
mirroring those of Kunert's texts; Kunert sometimes addressed envelopes to Schwaen with a provocative "An Kurt Schwaen/ (lockt und tötet Hörer)" [To Kurt Schwaen/ entices and kills listeners] or "An Wolfgang Amadeus Giacomo Schwaen/ Opern en detail \& en gros" [operas in detail and in the rough]. ${ }^{30}$ Kunert liked to sign his correspondence "Hausdichter" (House Poet). That Schwaen completed his Kunert settings in 1979, the year of his friend's emigration to the West, indicates the room their friendship held for the political tensions in divided Germany.

Schwaen worked on the eleven-song Liebsame Beschäftigung cycle over two decades, drawing mostly on Kunert's early anti-war texts; breaks in their collaboration likely reflected Kunert's distancing from the GDR, if not directly from his friends remaining there. Schwaen's settings of his texts range widely in style at the associative level, though the composer took his own trickster approach to genre and would not have wanted his songs reduced to type. Several songs recall ballad and lullaby, while others evoke the percussive "city music" of Hanns Eisler. The Lied-like "Ich lebe" ("I live") seems to anticipate Stephen Sondheim in its melodic turns. The short, strophic song "Begegnung in der Frühe," mentioned above, could be said to parody Schoenbergian non-redundancy (the avoidance of repeated pitches in the twelve-tone series) with haunting charisma. This associative slipperiness keeps the cycle from being heard as a safely contained whole; the mountaineering ballad, with its Communist-inflected warning about the consequences of a climber's thinking only of himself, comes as a bitterly jaunty shock.

Overall, the poems Schwaen chose tend toward duple meter, in rhymed pentameter, hexameter, or elegiac (in the Greek syllabic-metric sense) couplets combining the two. This metric regularity becomes a default mode against which Schwaen's settings can play. Sometimes a whole song will pull against the textual meter, as in the stark treatment of violence in peace- and wartime, "Der Pflaster ist getränkt" ("The plaster is [blood-]soaked"), which treats Kunert's oracular hexameter melismatically, stretching one syllable over several notes, in a 6/8 allegretto. Schwaen adds to this tug-of-war quality with two-againstthree passages in which dance-like piano patterns destabilize plodding vocal lines. In many cases, the cycle sets up patterns only to disrupt them (a favorite move of Eisler's as well), shifting from 3/4 to 2/4 time or breaking suddenly into 5/4. The final song, "Abends gehe ich" ("In the evening I go"), works as an ironic reflection on what has come before, as the singer performs a flâneur-like stroll through the oncedevastated but now ordinary city; the song is scored as an unmetered allegro, with measures that feel like $4 / 4$ but then require the singer to lean into the next bar on half a beat, against irregular triplet-like patterns in the piano. Something is awry on this "pleasant" city walk.

Figure 1: "Abends gehe ich"31

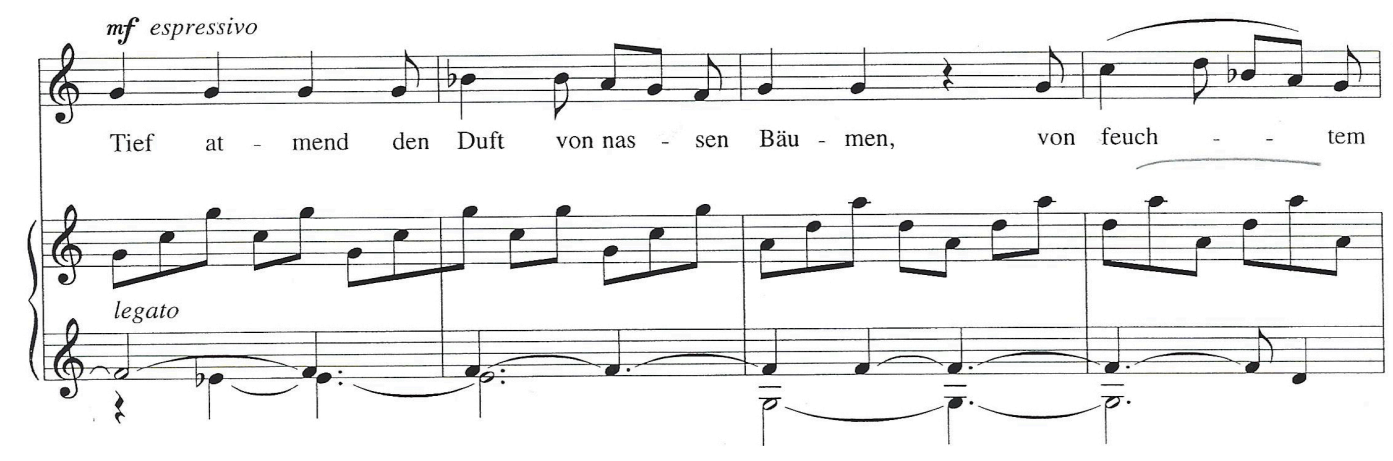

\footnotetext{
${ }^{30}$ Ibid., 125.

${ }^{31}$ Musical examples used by permission of Verlag Neue Musik.
} 
Schwaen recalls working with the East Berlin singer Gisela May, who particularly appreciated the Liebsame Beschäftigung cycle but experienced, not surprisingly, difficulties with Schwaen's rhythmic writing. ${ }^{32}$ This metric instability works against what Hanns Eisler called the "narcotic" effect of music, ${ }^{33}$ from the collective entrainment of march rhythms to the hypnotic "swamp" (Nietzsche's charged metaphor) of Wagner. ${ }^{34}$ Though some Eisler scholars argue for this metric shift his "Solidarity Song" as simply a shift toward greater momentum, my sense is that this break plays against the body politic's lockstep tendency with its 2/4 interruption in the midst of what could otherwise become an uncritical, predictable march. In addition to Eisler's influence, Schwaen's experience as an experimental-dance pianist during the war had certainly fostered his improvisational sense of time. Comparing his improvisation in Mary Wigman's Berlin studio to piano music for traditional ballet, Schwaen recalled, "Beim Ausdruckstanz war es völlig anders. Die Zeit schien nicht zu existieren, und so vollzog sich der Aufbau scheinbar ohne Maß und Gesetz"35 ("With expressive dance, it was completely different. Time seemed not to exist, and so the composition took place apparently without measure or rule").

At the metric-syllabic level, Kurt Schwaen's Kunert settings activate a subtler Verfremdungseffekt than the 2/4 "break" in Eisler's "Solidarity Song"; this music draws attention to syllables as syllables, reminding the performers and listeners (both groups seen as full participants, according to the Brechtian model) that singing speech is an unnatural act, and that voicing words about wartime atrocities is especially difficult. That these songs attempt it anyway reflects Günter Kunert's own sense that the forces of destruction in the world have already had their musical say, but that silence doesn't help: "Besser, singend Menschlichkeit zu zeigen" 36 ("Better, to show humanity, singing"), however halting the words. By setting up and breaking syllabic-metric conventions, rather than subtly working against the notated meter as in Brahms' "displaced downbeats" amid already complex hemiola, ${ }^{37}$ leading in that case to what Harald Krebs has called "subliminal dissonance," 38 Schwaen foregrounds the awkwardness of speech attempted as song. These rhythmic breaks do not set up new syncopated patterns or mirror affective discomfort without disrupting normal stress-accentual speech patterns, as in some of Schumann's songs. ${ }^{39}$ Rather, Schwaen's instability works as momentary "displacement dissonance" ${ }^{* 0}$ that listeners may experience as discomfitingly random. Several examples of dislocated/estranged syllables will demonstrate this phenomenon.

The first song of the Liebsame Beschäftigung cycle, "Betrachtung" ("Reflection"), plays with and against percussive, speech-like text to describe collective anxiety behind walls and closed doors. The song's break into what would normally sound as broad, lyric phrasing is marked with heavy accents, returning at the end to clicking one-note-per-syllable eighth notes. In the opening phrase, Schwaen sets a normally unstressed syllable on a rising pitch, associated with stressed syllables in traditional musical prosody. In all three verses, the fourth eighth-note beat of the first bar noted below would fall on an unstressed syllable in

\footnotetext{
${ }^{32}$ Ibid., 96.

${ }^{33}$ Hanns Eisler, "Fortschritte in der Arbeitermusikbewegung," in The Weimar Republic Sourcebook, eds. Anton Kaes, Martin Jay, and Edward Dimendberg (Berkeley: University of California Press, 1994), 241.

${ }^{34}$ See Friedrich Nietzsche, Der Fall Wagner (Munich: dtv, 1999).

${ }^{35}$ Ibid., 32.

${ }^{36}$ Günter Kunert, Das kreuzbrave Liederbuch (Berlin: Aufbau, 1961), backmatter.

${ }^{37}$ Yonatan Malin, Songs in Motion: Rhythm and Meter in the German Lied (New York: Oxford University Press, 2010), 61, https://doi.org/10.1093/acprof:oso/9780195340051.001.0001.

${ }^{38}$ Harald Krebs, Fantasy Pieces: Metrical Dissonance in the Music of Robert Schumann (New York: Oxford University Press, 1999), 46-52, https://doi.org/10.1093/acprof:oso/9780195116236.001.0001.

${ }^{39}$ See ibid., 156-171.

${ }^{40}$ Malin, 52.
} 
speech but gains more emphasis rising from $G$ to $A$. This subtle move is most notable in the third verse, which also plays semantically on the word "gleichermaßen," meaning "equally" or "even-handedly."

Figure 2: "Betrachtung"

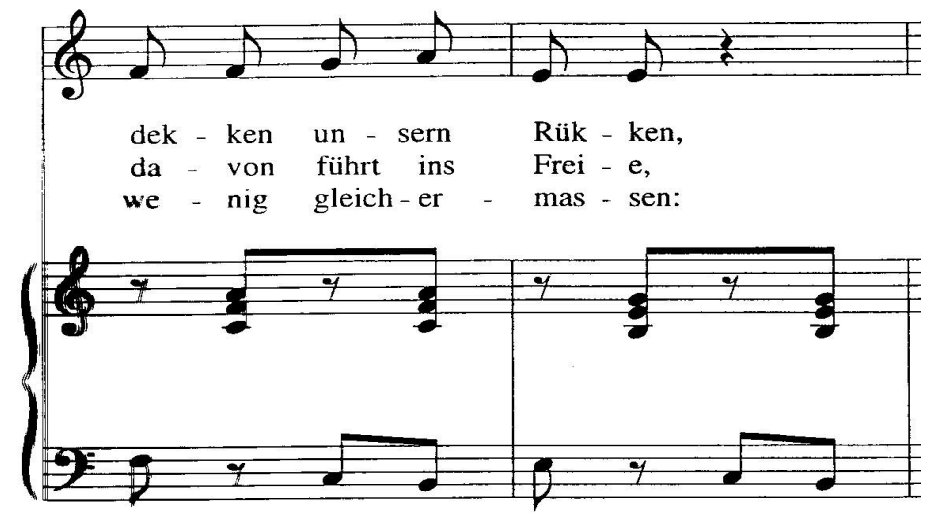

Part of this disruption arises simply from the act of strophic writing, requiring varying texts to fit the same melodic line; Schwaen adds to this artificiality in a song that sets itself up as a marchlike "Manifest" 41 ("Manifesto") but undermines its own project with abrupt tonal and rhythmic shifts.

In the second song, the sharply playful "Das Gedicht vom Mond" ("Poem About the Moon") mentioned above, word repetitions occur in changing time signatures, destabilizing the song's triple meter with a break into duple time.

Figure 3: "Das Gedicht vom Mond"

\section{Tempo I}

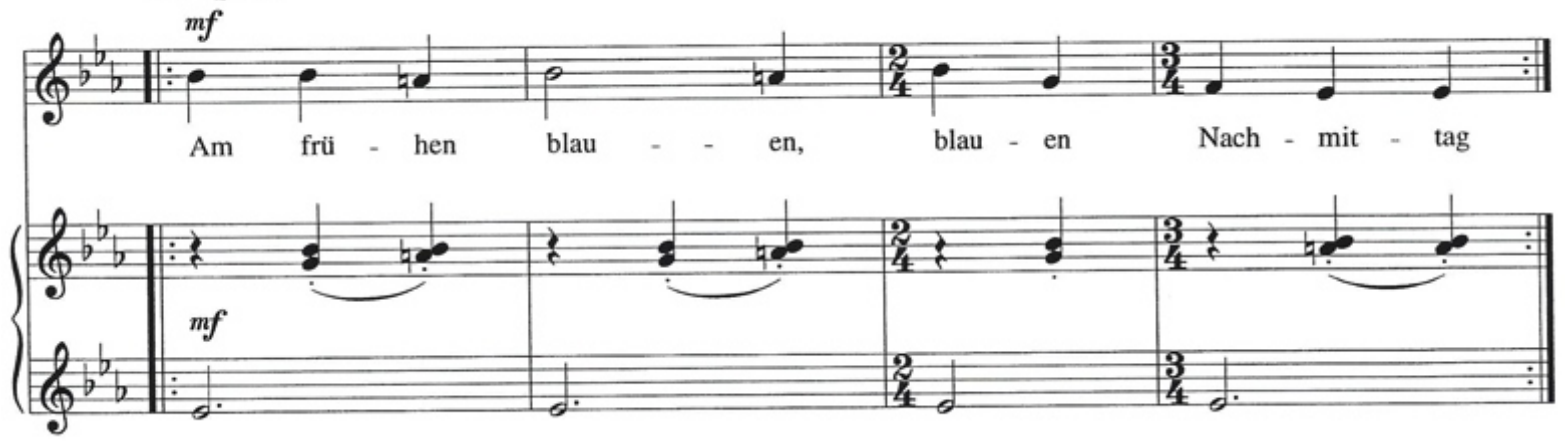

In the fourth, doomed-mountaineers' song, strophic scoring with a 5/4 break and syncopated melodic lines force the singer to adapt each verse's words to already irregular metric patterns, adding a sense of selfconscious artificiality to what might otherwise come across as a predictable Communist cautionary tale. The cycle's title song, its sixth, is a Brechtian if surreal Lebensbericht, or life report, on a city made of skeletal

${ }^{41}$ Kurt Schwaen, Liebsame Beschäftigung: 11 Lieder nach Gedichten von Günter Kunert für Gesang und Klavier (Berlin: Verlag Neue Musik, 1994), 2. 
trees, burning gasoline, and soldiers waking from the dead. It ends with another word repetition, the verb "vergessen" articulated with varying rhythmic emphases; the song refuses to soften this "forgetting," as the poem's speaker pictures cars and trains pulsing by, occupied only by denying the city's past:

Figure 4: "Vom Besteigung hoher Berge"

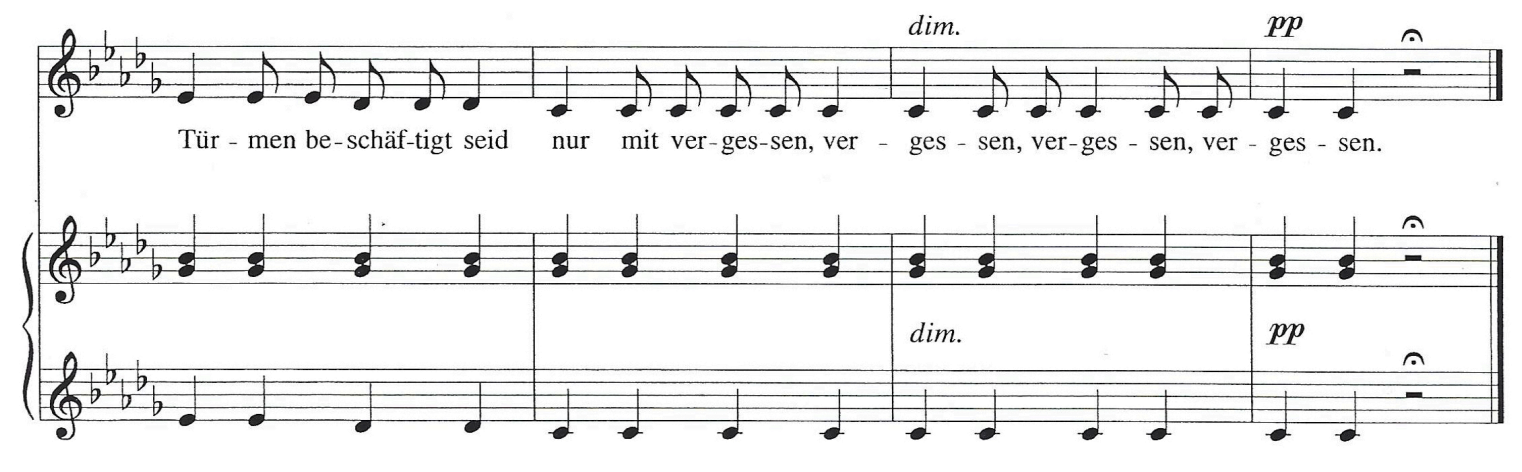

The speaker/singer is as painfully awake as the dead soldiers, voicing what only she seems able to perceive amid collective urban routine.

"Es brauchen die Kinder Ruhe" ("Children need peace"), the cycle's seventh song, is a plea for teaching children nonviolence. It begins in a rocking 3/4 time that breaks into an unmetered recitative-like passage marked "frei etwas schneller" ${ }^{42}$ (freely, somewhat faster), jolting musicians and listeners out of what could become a gentle trance, as the text warns against habituating children to violent images. This song may be the best example of dialectical music in Liebsame Beschäftigung, with opposing elements in stark juxtaposition. The songlike/declamatory collision does not yield to synthesis, as in Hegelian dialectics, but rather remains in unresolved tension, as Brecht intended in his Lehrstïcke. ${ }^{43}$ The cycle's final song, the unmetered "Abends gehe ich," another life-report while on a city walk, gives what looks like an even eighth-note pattern an asymmetrical quality, with increasingly truncated bars (Figure 5), and emphasizes "throwaway" prepositions and articles with melisma (Figure 6).

What might otherwise work as a predictable "walking" beat becomes a kind of stumbling; again, this is a solitary speaker/singer functioning as a critically uncomfortable witness, even on a jaunty walk. This final song ends with no postlude, as would be typical for final songs in Lieder-style cycles, but rather a sung citation of the "Solidaritätslied" and a quick, loud piano chord in the bass, right after the singer's last word, "zu," a preposition held, oddly, on a long tied note.

In Kunert's notes to the 1961 edition of his poems, which includes some facsimile samples of Schwaen's settings, he includes information on where "vom romantischen Kunstlied Ermüdeten" ("those tired of romantic art song") can find more of the poet and composer's collaborative work. This is music meant to estrange and destabilize the bourgeois Liederabend tradition, while at the same time allowing music and poetry a critical-kinetic power. As Kunert put it amid the lyric-poetry debate of the

\footnotetext{
42 Ibid., 15.

${ }^{43}$ See Andreas Aurin, "Dialectical Music and the Lehrstück: An Investigation of Music and Music-Text Relations in This Genre," doctoral thesis, School of the Arts and Media, University of New South Wales, 2014.

${ }^{44}$ Kunert, Das kreuzbrave Liederbuch, 89.
} 
Figure 5: "Abends gehe ich"
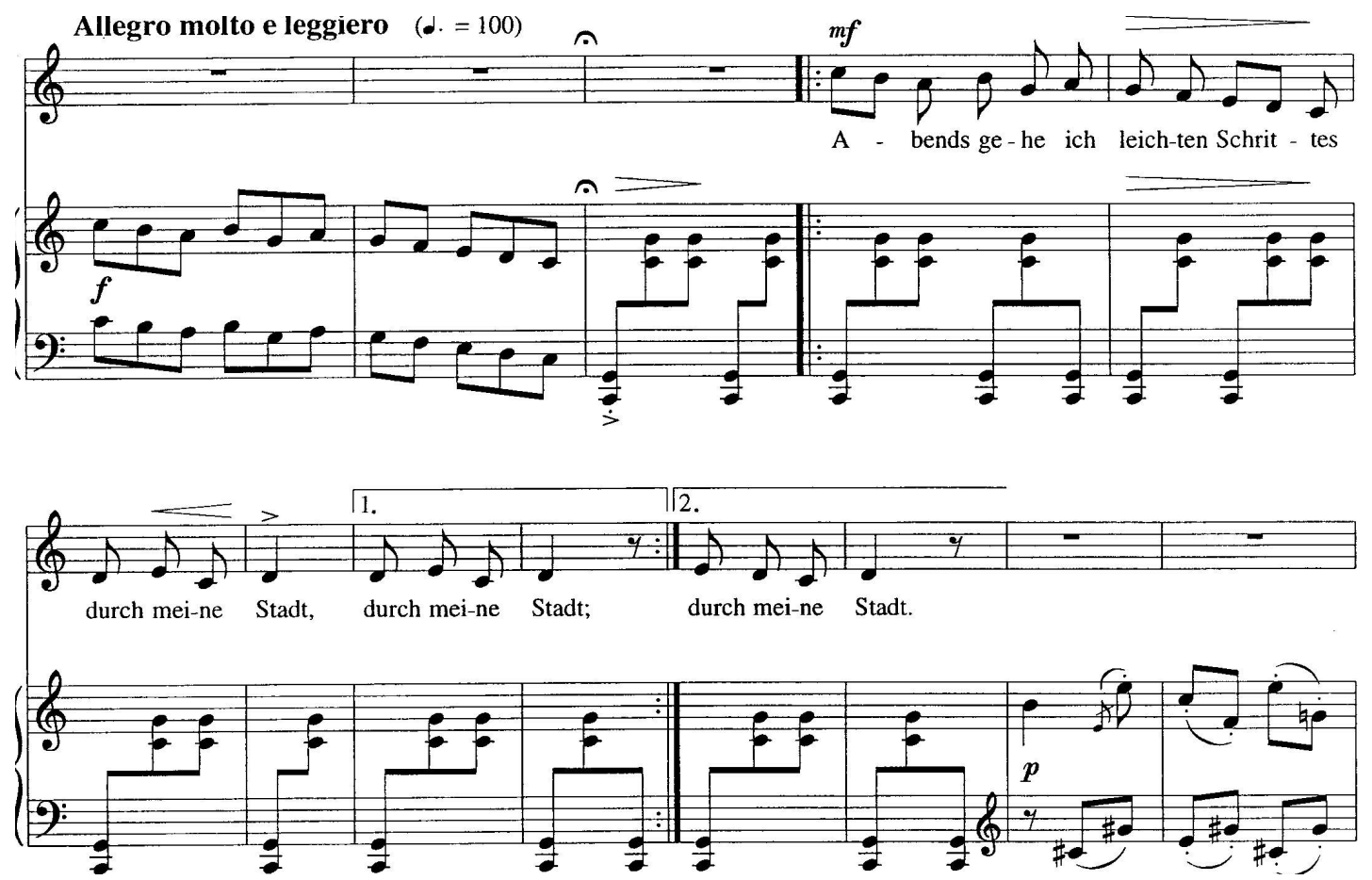

Figure 6: "Abehnds gehe ich"
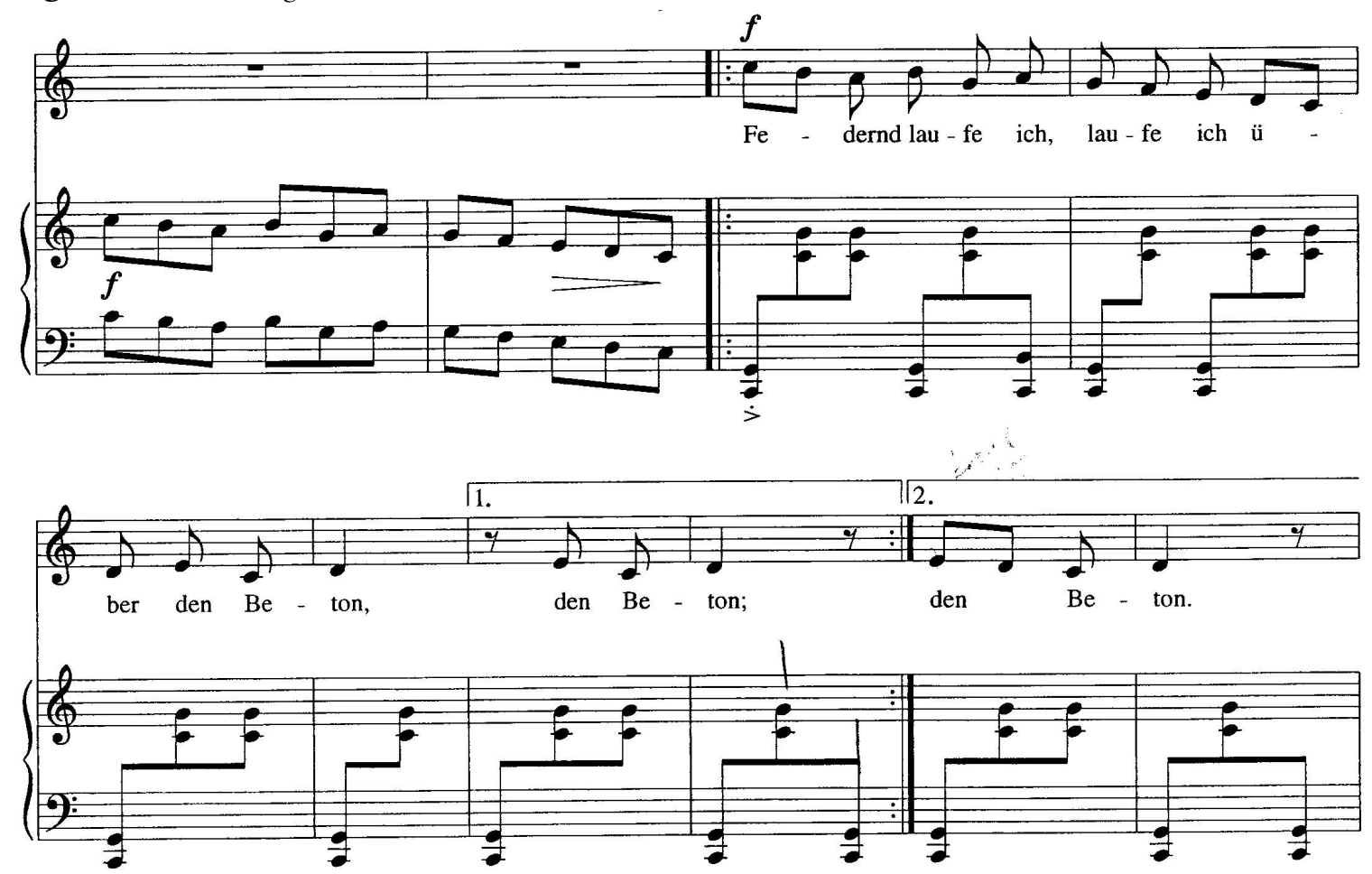
early 1980s, poets are "seismographs" attuned to their world's "Erschütterungen"”45 or "shudderings," a term also used by Walter Benjamin to indicate "shock." ${ }^{46}$ In Schwaen's text settings, the result is both the kind of homeopathy Jameson detects in Brecht, as de-reification through reification of isolated or estranged speech parts, keeping performers and listeners critically alert, and a phenomenological discomfiting of the song-recital experience. The apparent randomness of some syllabic emphases is part of "the Brechtian staging of the gestus, and the insistence on showing the audience that any number of other versions of these gestures and reactions might have been possible in other frames and other situations." ${ }^{47}$ How to pull off such an engagement with contingency in a musical event? Schwaen framed his intention for the performance of these songs as a question:

Für welche Stimmen ist dies geschrieben? Der Opernsänger wird kaum etwas Passendes finden. Eher singende SchauspielerInnen. Sie werden den Texten wie der Musik die Aufmerksamkeit widmen, die sie beanspruchen. ${ }^{48}$

For which voices is this written? The opera singer will find hardly anything suitable. Better singing actors. They will dedicate the attention to the texts as to the music that both require.

The key word here is "Aufmerksamkeit" - attention, noticing, marking, refusing to take sung words for granted. For a singer, this means intense attention to detail and a willingness to let the unnaturalness of her own act surprise in performance, especially when she sings about bullet-riddled bodies or enacts a twelve-tone parody that could be a love song to person or a damaged city. In a time when the specters of far-right populism and white nationalism are rising again in Europe and in the U.S., the "employment" or "pursuit" of attention to painful news keeps these syllables speaking.

\section{Works Cited}

Andresen, Geertje. Oda Schottmüller 1905-1943: Die Tänzerin, Bildhauerin und Nazigegnerin. Berlin: Lukas Verlag, 2005.

Aurin, Andreas. "Dialectical Music and the Lehrstïck: An Investigation of Music and Music-Text Relations in This Genre." Doctoral thesis, School of the Arts and Media, University of New South Wales, 2014.

Brecht, Bertolt. "Kleines Organon für das Theater." In Werke. Große kommentierte Berliner und Frankfurter Ausgabe, edited by Werner Hecht, Jan Knopf, Werner Mittenzwei, and Klaus-Detlef Müller, 65-105. Vol. 23, Schriften 3. Frankfurt: Suhrkamp, 1993.

Benjamin, Walter. "On Some Motifs in Baudelaire." In Illuminations, edited by Hannah Arendt and translated by Harry Zohn, 155-200. New York: Schocken Books, 1968.

Bloch, Ernst and Hanns Eisler, "Die Kunst zu Erben.” In Die Expressionismusdebatte: Materialien zu einer marxistischen Realismuskonzeption, edited by Hans-Jürgen Schmitt, 258-263. Frankfurt: Suhrkamp, 1973.

\footnotetext{
${ }^{45}$ Elke Kasper, "Untergangs- oder Überlebenskunst? Eine Lyrikdebatte und ihre Folgen,” in Günter Kunert: Beiträge zu seinem Werk, 106-107.

${ }^{46}$ See Walter Benjamin, "On Some Motifs in Baudelaire," in Illuminations, ed. Hannah Arendt and trans. Harry Zohn (New York: Schocken Books, 1968), 160-161, 174-175. For the original German version, see Benjamin, "Über einige Motive bei Baudelaire," in Illuminationen: Ausgewählte Schriften (Frankfurt: Suhrkamp, 1955), 185-229.

${ }^{47}$ Fredric Jameson, "Persistencies of the Dialectic: Three Sites," in Dialectics for the New Century, eds. Bertell Ollman and Tony Smith (New York: Palgrave Macmillan, 2008), 128, https://doi.org/10.1057/9780230583818 8.

${ }^{48}$ Schwaen, Liebsame Beschäftigung, 28.
} 
Bunge, Hans. Fragen Sie mehr über Brecht: Hanns Eisler im Gespräch. Munich: Rogner and Bernhard, 1976.

Durzak, Manfred and Hartmut Steinecke, eds. Günter Kunert: Beiträge zu seinem Werk. Munich and Vienna: Carl Hanser, 1992.

Eisler, Hanns. "Fortschritte in der Arbeitermusikbewegung." In The Weimar Republic Sourcebook, edited by Anton Kaes, Martin Jay, and Edward Dimendberg, 240-242. Berkeley: University of California Press, 1994.

Emmons, Shirlee, and Stanley Sonntag, The Art of the Song Recital. New York: Schirmer Books, 1979.

Hanson, Alice M. "Vienna, City of Music." In Schubert's Vienna, edited by Raymond Erickson, 98-118. New Haven and London: Yale University Press, 1997. https://doi.org/10.2307/j.ctt1ww3v2b.11.

Jameson, Fredric. Brecht and Method. London: Verso, 1998.

. "Persistencies of the Dialectic: Three Sites." In Dialectics for the New Century, edited by Bertell Ollman and Tony Smith, 118-131. New York: Palgrave Macmillan, 2008. https://doi.org/10.1057/9780230583818_8.

Kelly, Elaine. Composing the Canon in the German Democratic Republic: Narratives of Nineteenth-Century Music. Oxford: Oxford University Press, 2014. https://doi.org/10.1093/acprof:oso/9780199998098.001.0001.

Krebs, Harald. Fantasy Pieces: Metrical Dissonance in the Music of Robert Schumann. New York: Oxford University Press, 1999. https://doi.org/10.1093/acprof:oso/9780195116236.001.0001.

Kunert, Günter. Das kreuzbrave Liederbuch. Berlin: Aufbau, 1961. . Mein Lesebuch. Frankfurt: Fischer Taschenbuch Verlag, 1983.

Malin, Yonatan. Songs in Motion: Rhythm and Meter in the German Lied. New York: Oxford University Press, 2010. https://doi.org/10.1093/acprof:oso/9780195340051.001.0001.

Nietzsche, Friedrich. Der Fall Wagner. Munich: dtv, 1999.

Rosen, Charles. The Romantic Generation. Cambridge, MA: Harvard University Press, 1995.

Schwaen, Kurt. Liebsame Beschäftigung: 11 Lieder nach Gedichten von Günter Kunert für Gesang und Klavier. Berlin: Verlag Neue Musik, 1994.

__. "Nocturne lugubre." Berlin: Verlag Neue Musik, 1996.

- Stufen und Intervalle: Ein Komponist zwischen Gesellschafts- und Notensystemen. Essen: Die Blaue Eule, 1996.

\begin{abstract}
After his three-year imprisonment as a Communist under the Nazi regime, composer Kurt Schwaen worked as a pianist for an experimental dance theater in Berlin. This experience, combined with the influences of Hanns Eisler and Eastern European dance music, intensified Schwaen's sensitivity to the kinetic power of rhythm in music, with its potential to support or undermine collective ideology. Best known for his collaborative work with Bertolt Brecht and for his songs composed for school children in the German Democratic Republic, Schwaen was also a prolific composer of music for voice, piano, instrumental ensembles, theater, and film. This article investigates Schwaen's 1957-1979 song cycle set to politically inflected poems by Günter Kunert, Liebsame Beschäftigung, with attention to stress-accentual irregularity as a form of Brechtian estrangement. In many vocal phrases, Schwaen places a normally
\end{abstract}




\section{Music and Politics Winter 2018}

unstressed syllable on a downbeat or rising point in the melodic line, or draws out a preposition melismatically instead of emphasizing more semantically weighted speech units. This undermining of speech rhythm disrupts familiar kinetic-linguistic pacing to keep both performers and listeners from passive receptivity. A dialectical approach to text and music in Schwaen's cycle applies Fredric Jameson's point, in Brecht and Method, that reification of familiar elements can work in a homeopathic way to "dereify" them. As these musical settings draw attention to syllabic patterns normally taken for granted, they disturb the received, bourgeois Liederabend experience and foreground the sung text as an unnatural response to the horrors of war. 